\title{
NOMENCLATURAL AND TAXONOMIC NOTES IN PHYMATIDIUM GEISELII (ONCIDIINAE, ORCHIDACEAE)
}

\author{
A. L. V. Toscano de Brito ${ }^{1.3}$, Carla Adriane Royer ${ }^{2} \&$ Eric de Camargo Smidt ${ }^{2}$ \\ ${ }^{1}$ Marie Selby Botanical Gardens, 811 South Palm Avenue, Sarasota, FL 34236, U.S.A. \\ ${ }^{2}$ Universidade Federal do Paraná, Setor de Ciências Biológicas, Centro Politécnico, Jardim das Américas, \\ Cx. Postal 19031, Curitiba, PR., Brazil \\ ${ }^{3}$ Author for correspondence: atoscano@selby.org
}

Abstract. Phymatidium glaziovii is proposed as a new synonym for $P$. geiselii. A lectotype and an epitype are selected for $P$. geiselii. Illustrations and taxonomic discussions are also provided.

KeY worDs: Brazilian endemic species, Caparaó National Park, typifications

Introduction. Phymatidium Lindl. belongs to the Ornithocephalus group of subtribe Oncidiinae Benth. (Orchidaceae). It was established in 1833 based on two species, P. delicatulum Lindl. and P. falcifolium Lindl., the former the designated lectotype, which was selected by Angely in 1973. The genus has been extensively studied during recent years. Data on root anatomy (Porembski \& Barthlott, 1988), leaf anatomy and seed morphology (Toscano de Brito 1988, 1999), vegetative and floral morphology (Toscano de Brito 2001, Pacek et al. 2012), phytochemistry (Williams et al. 1994, Reis et al. 2006), pollination (Reis et al. 2006), phylogeny (Chase \& Toscano de Brito 2009, Royer 2013), distribution (Royer, 2013) and reproductive biology (Cabral \& Pansarin, 2013) are available in the literature. A taxonomic revision was published by Toscano de Brito (2007). According to this last author, the genus comprises ten species and two varieties, which are mainly restricted to southeastern Brazil with one species recorded from Uruguay and another from Argentina.

While preparing an account of the genus Phymatidium in the state of Paraná (Royer et al., 2014), and performing a combined morphological and molecular analysis of the genus (Royer, 2013), the morphologies and identities of $P$. geiselii Ruschi et al. and P. glaziovii Toscano were investigated and elucidated. These species are discussed here.

Material and methods. This study is based on literature review, on examination of living and spirit collections, and herbarium specimens deposited in the following herbaria: AMES, BHCB, BR, C, HB, MBML, P and UPCB.

\section{Results and Discussion}

Phymatidium geiselii Ruschi et al., Bol. Mus. Biol. Mello-Leitão, Sér. Bot. 85: 1. 1976. TYPE: Brazil. Minas Gerais (Espírito Santo, in error): Parque Nacional do Caparaó, Rio São Domingos, Várzea dos Congonhas (Macieira), 16 August 1975, A. Albuquerque et al. s.n. (holotype MBML-spirit 6220 , lost). Lectotype designated here: Augusto Ruschi's illustration, which appeared in Boletim do Museu de Biologia Prof. Mello-Leitão, Série Botânica 85: 3. 1976. Epitype designated here: Brazil. Minas Gerais: Parque Nacional do Caparaó, entrada do ES, caminho entre Macieira e Cachoeira do Aurélio, 1915 m, 5 March 2010, G. Heringer, T.M. Machado \& S.B. Reis 295 (BHCB 135957!). Fig. 1-4.

Synonym: Phymatidium glaziovii Toscano, Kew Bull. 62: 538. 2007. TYPE: Brazil. Rio de Janeiro, s.d., A. Glaziou 3633 (holotype BR 658606!, isotypes: C 10016286! P 00436655!), syn. nov.

Phymatidium geiselii was described in 1976 based on a specimen collected in Caparaó National Park, in the state of Espírito Santo, southeast Brazil. The specimen was collected by Antonio Francisco Marins de Albuquerque and later preserved in spirit at MBML. 


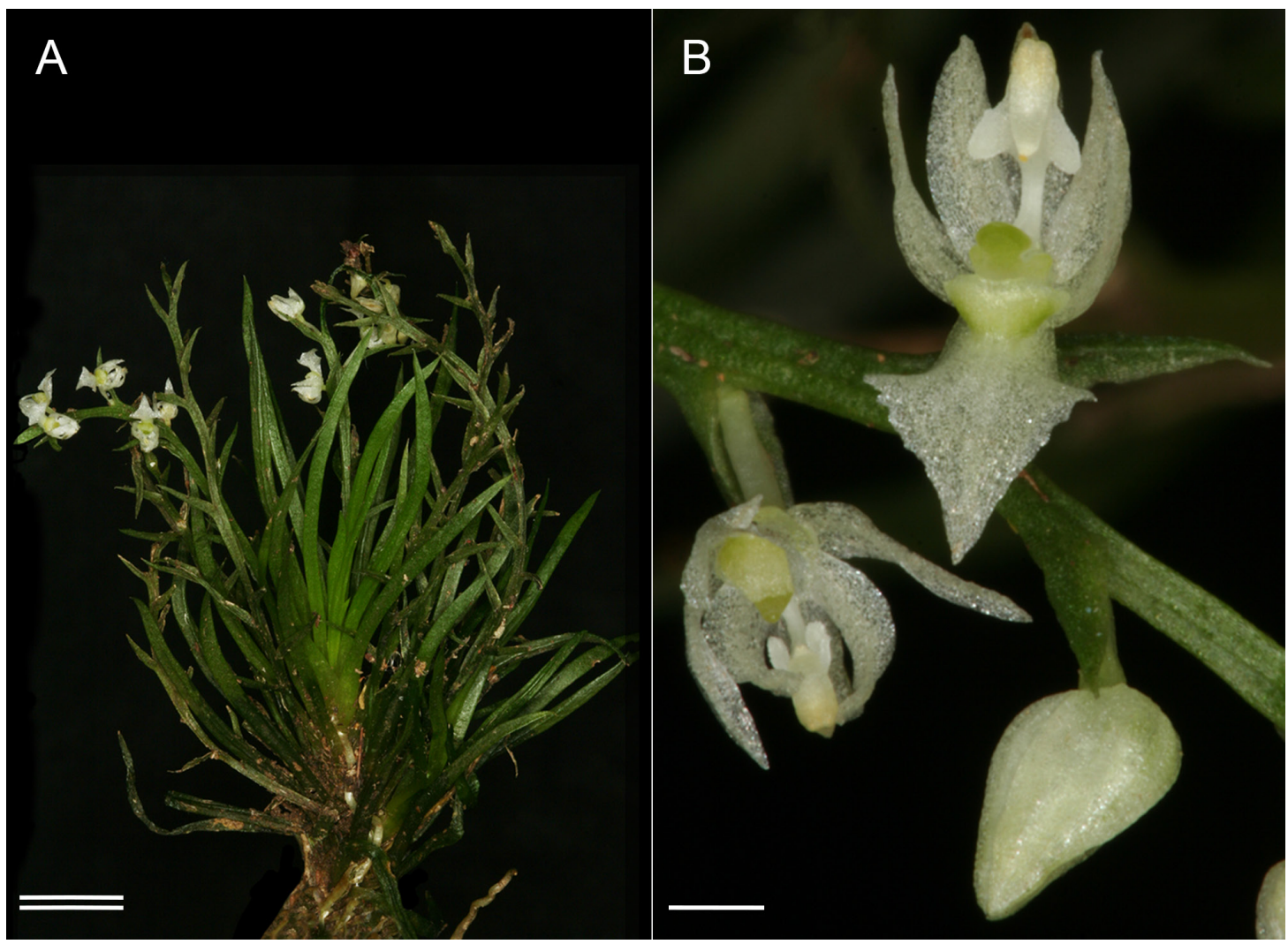

Figure 1. Phymatidium geiselii. A. Habit. B. Flower. Based on a specimen from Serra dos Orgãos National Park, Teresópolis,

Rio de Janeiro (M. Bolson et al. 505). Photograph by E. Smidt. Single line $=1 \mathrm{~mm}$. Double line $=1 \mathrm{~cm}$.

The type species of $P$. geiselii has been reported as lost (Toscano de Brito, 2007), and a recent visit to MBML has confirmed this. According to MBML's staff, the specimen MBML 6220 is actually a member of the Bromeliaceae (T. Callot, pers. comm. 2015). Three other collections named as $P$. geiselii exist at MBML. These have no provenance or collectors. According to A. Albuquerque (pers. comm. 2015), collector of the holotype of $P$. geiselii and one of the co-authors of this taxon, the additional specimens might have been collected sometime between 1975 and 1977 and may have the same provenance as the type. Unfortunately, we have been unable to find any further evidence confirming this assumption. These specimens possess immature fruits with flower remnants at their apices. An illustration based on one of them (nr. 29, MBML 6127) was prepared and published in Toscano de Brito (2007, fig. 2A-K). The floral remnants of that specimen are unfortunately somewhat shrunk and distorted, especially the tabula infrastigmatica, as noticed by Toscano de Brito (2007).

Phymatidium geiselii is a small plant up to ca. $7 \mathrm{~cm}$ tall. (Fig. 1A; 4L). The roots are glabrous; the spirally arranged, non-articulated leaves are obscurely sheathing and shortly decurrent at base, unifacial, somewhat twisted and variable in cross-section: subtriangular to semiterete (Fig. 4K). The flowers do not open widely (Fig. 1B; 4A-C) and are usually not resupinate, but resupinate and non-resupinate flowers can occur in the same individual and on the same inflorescence; they are white with green tabula infrastigmatica and callus (Fig. 1B). The lip varies from broadly ligulate to broadly lanceolate in outline and obscurely to distinctively three-lobed, with lateral lobes usually placed in the middle; the basal, fleshy, concave callosity is provided with trichomeelaiophores within, and the apex of the lip is usually markedly acuminate (Fig. 4G). The column (Fig. 4H) is curved and obscurely sigmoid in side view, the apex is auriculate and the auricles papillose; the anther is 


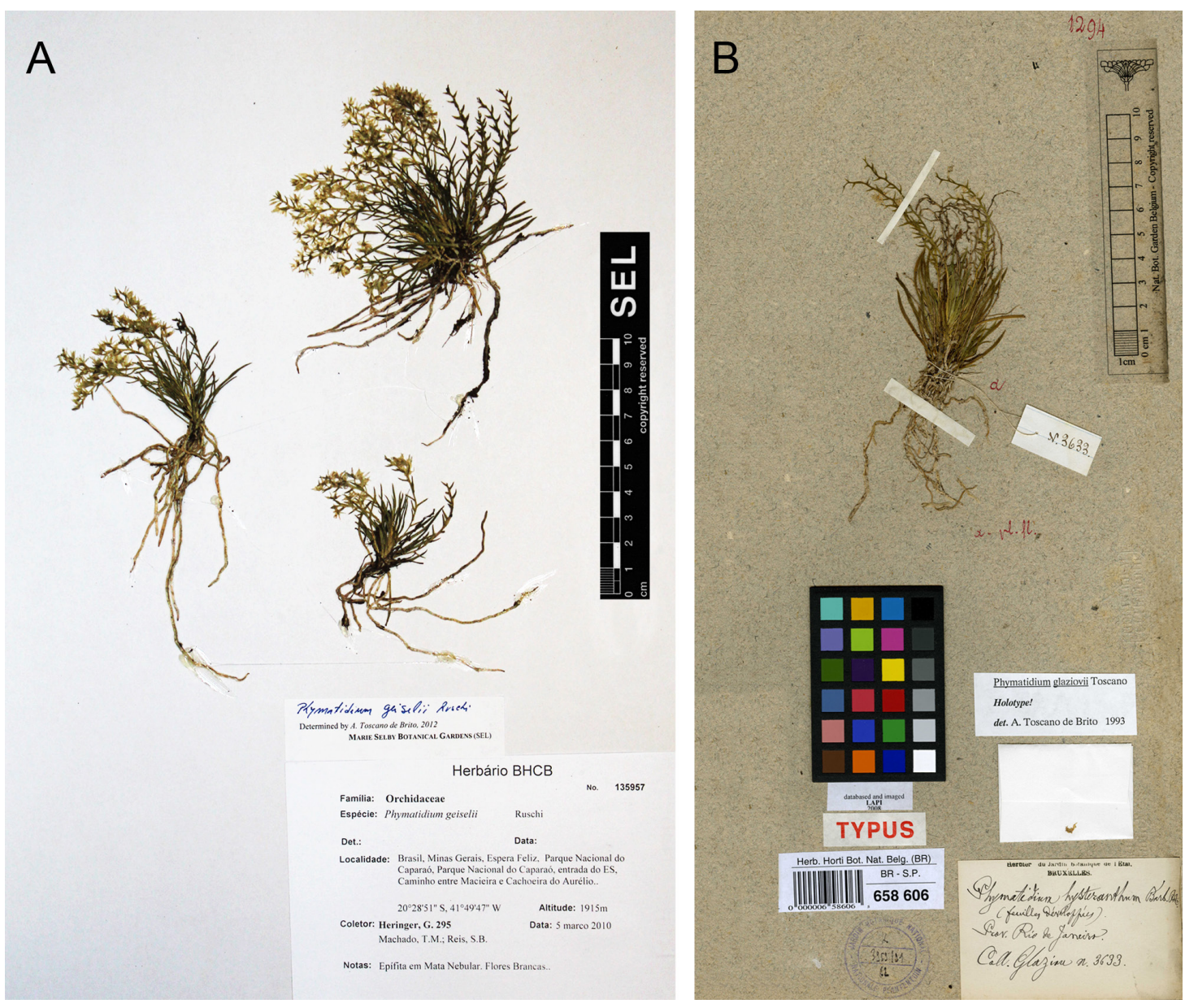

Figure 2. A. Epitype of Phymatidium geiselii proposed here: G. Heringer, T.M. Machado \& S.B. Reis 295 (BHCB).

Photograph by A. Toscano de Brito. B. Holotype of Phymatidium glaziovii deposited at BR. Reproduced with permission. Copyright: Jardin Botanique Meise.

operculate, narrowly ovate in outline, slightly beaked, and shortly recurved and emarginated at apex (Fig. 4I-J); the tabula infrastigmatica is conspicuous and nose-shaped in side view.

The type specimen of Phymatidium geiselii was collected in the Caparaó National Park, which is located in the border of the Brazilian states of Minas Gerais and Espírito Santo, and it is said to have been collected in the Espírito Santo side of the Park. However, places such as Rio São Domingos, Várzea dos Congonhas, and Macieira are located, as far as we can ascertain, in the Minas Gerais portion of the Park. The area where the type specimen of $P$. geiselii was collected has been the subject of an ongoing dispute between these two states and the exact limits are open for discussion (A.
Albuquerque, pers. comm. 2015). For the purpose of this article, we accept Minas Gerais as the state where $P$. geiselii has been first collected. The German botanist Alexandre C. Brade (1881-1971) has extensively botanized in this area. According to him (Brade, 1942), localities such as Várzea dos Congonhas may reach ca. $2000 \mathrm{~m}$ above sea level.

Phymatidium glaziovii was described by Toscano de Brito (2007) based on a collection by the French botanist Auguste F. M. Glaziou (1828-1906) in the city of Rio de Janeiro. Glaziou did not provide a precise locality or date for his collection. "Rio de Janeiro" certainly refers to what today is the city of Rio de Janeiro and its surroundings. The holotype of P. glaziovii is now deposited at BR (Fig. 2B) and an 

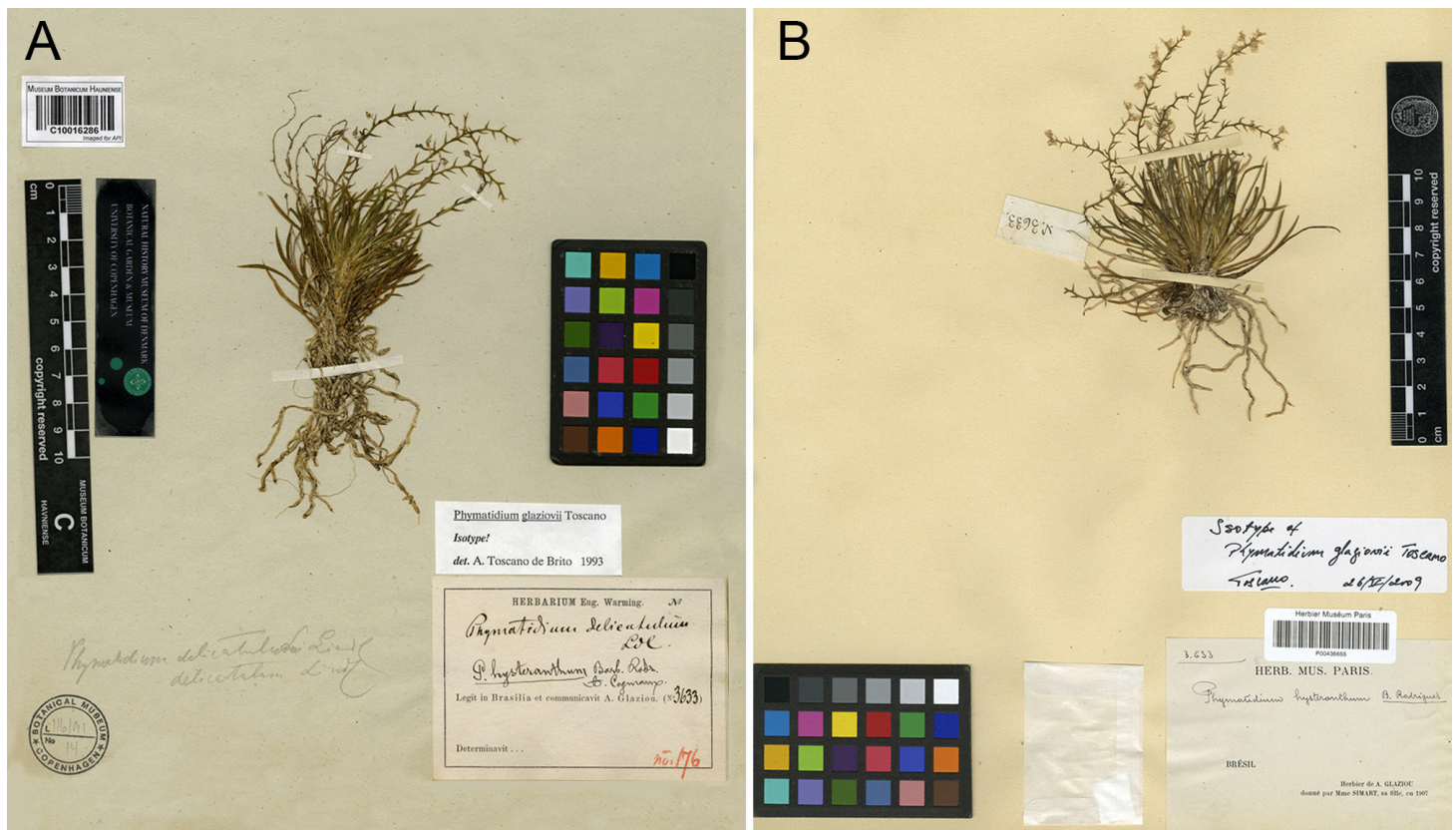

FIgURE 3. A. Isotype of Phymatidium glaziovii deposited at C. Reproduced with permission of the Natural History Museum of Denmark. B. Isotype of Phymatidium glaziovii deposited at P. Reproduced with permission of the Muséum National d'Histoire Naturelle (Paris).

isotype is at $\mathrm{C}$ (Fig. 3A). More recently, one of us (ALVTB) located and studied an additional duplicate from Glaziou 3633 at P (Fig. 3B).

The distorted floral segments of the $P$. geiselii specimens at MBML misled Toscano de Brito (2007), who considered $P$. geiselii and $P$. glaziovii distinct species. This author described the fruits of $P$. geiselii as "markedly 3-winged with alternating, usually less pronounced ridges", and used this character, along with lip shape, to distinguish $P$. geiselii from $P$. glaziovii. The latter would have subglobose fruits that are slightly 3 -angled in cross section. The type specimens of $P$. glaziovii possess a few scattered, immature fruits that are still in an early stage of development. Therefore, correct size of ridges and wings of fully developed, mature fruits cannot be precisely determined and was misinterpreted in Toscano de Brito's revision. One collection from Rio de Janeiro, J. Ferreira 1716, with duplicates in several herbaria, carries fruits, which, although badly flattened in the drying process, are clearly ridged and apparently somewhat winged. The collection J. Ferreira 1716 was erroneously identified and illustrated as a variant of $P$. delicatulum in Toscano de Brito (2007, fig. $1 \mathrm{~K}-\mathrm{L}$ ). It actually refers to $P$. geiselii and this error is corrected here. Likewise, the specimen $O$. Ames 108, from Itatiaia, Rio de Janeiro, was also misidentified as a variant of $P$. delicatulum in Toscano de Brito (2007). It is in fact a specimen of $P$. geiselii.

We also studied eight additional collections, which fit well not only the fruiting specimens of $P$. geiselii illustrated in Toscano de Brito (2007), but also the types of P. glaziovii. Five collections come from the state of Rio de Janeiro: Two from the municipality of Itatiaia (J. Ferreira 1716, O. Ames 108), two from the municipality of Nova Friburgo (A. Bonnet and E. Caglioni 127, F. Dungs s.n.), and another from the municipality of Teresópolis (Bolson et al. 505). A sixth collection comes from Caparaó National Park $(G$. Heringer et al. 295) in the state of Minas Gerais. This last collection was found in the municipality of Espera Feliz, which is very close (if not the same) to the type locality of P. geiselii. Two others come from Domingos Martins, state of Espírito Santo. They were based on cultivated material and their actual provenance cannot be correctly ascertained. Study of all these additional specimens, including living, spirit, and herbarium material, has proved that $P$. geiselii and $P$. glaziovii are 

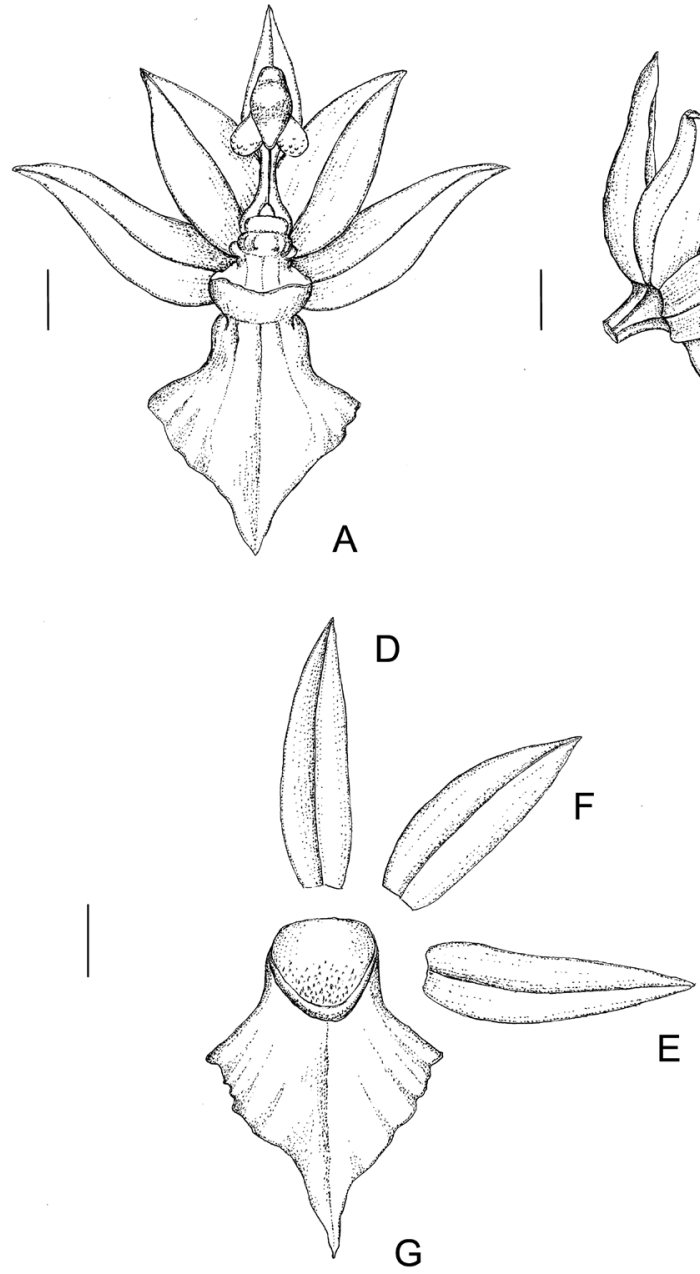

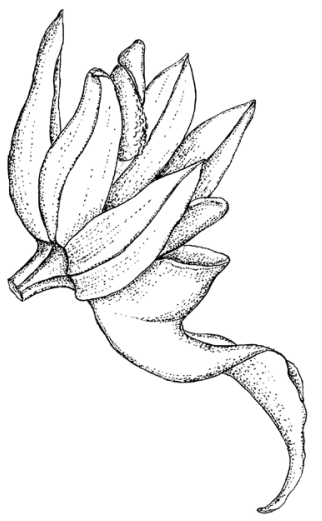

B
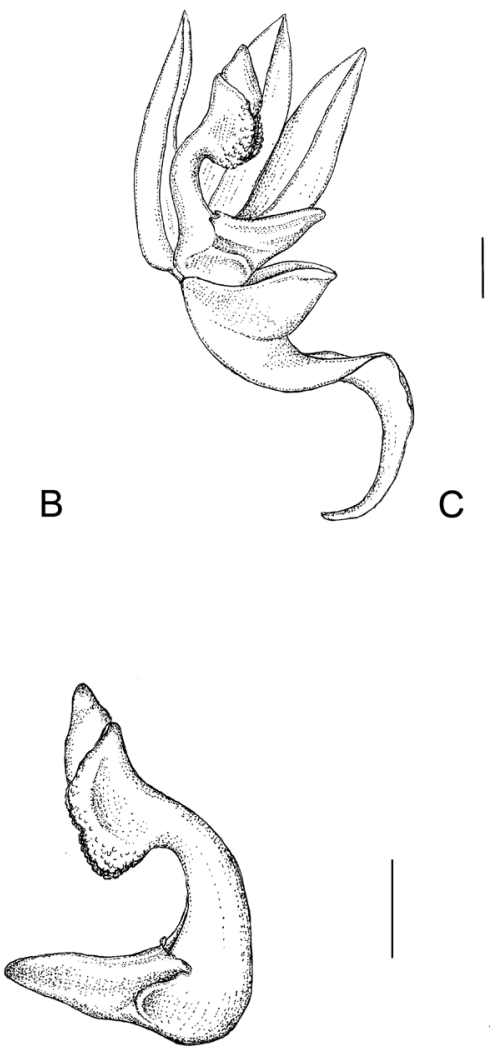

$\mathrm{H}$
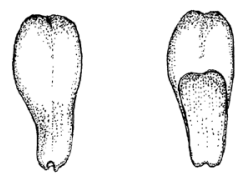

I

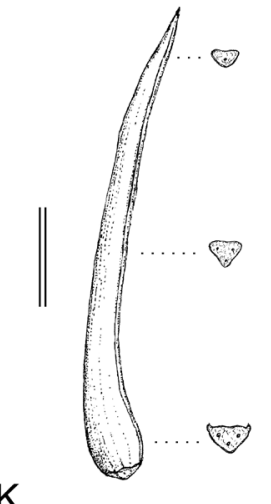

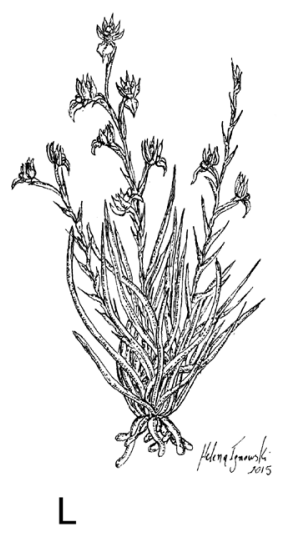

Figure 4. Phymatidium geiselii. A. Flower in front view. B. Flower in side view. C. Flower in side view, petal and proximal lateral sepal removed to show column and lip callus. D. Dorsal sepal. E. Lateral sepal. F. Petal. G. Lip. H. Column in side view. I. Anther in front view. J. Anther from behind. K. Leaf, transverse sections shown in approximate scale. L. Habit (M. Bolson et.al. 505, UPCB - spirit). Illustration by Helena Ignowski. Single line $=1 \mathrm{~mm}$. Double line $=1 \mathrm{~cm}$. 
With exception of the collections from Domingos Martins (R. Kautsky s.n.; F. Dungs s.n.) and the type specimens of $P$. glaziovii collected in Rio de Janeiro, which unfortunately lack precise location data and altitude range, the material studied seems to indicate that $P$. geiselii grows on higher altitudes up to $2200 \mathrm{~m}$.

In the absence of an actual specimen, the only original, extant materials of $P$. geiselii are the published description and illustration in the protologue. The illustration that appeared in the protologue is here designated as the lectotype. However, this illustration is crude and misleading. It cannot be used alone to recognize this species. Therefore, we select as an epitype the specimen G. Heringer et al. 295, which is deposited at BHCB (Fig. 2A). This specimen was collected in Caparaó National Park, the same locality as the type. The selection of this collection against the three spirit specimens at MBML $(6125,6126,6127)$, previously mentioned here, is justified as these have no collection data and are already in fruiting stage, bearing only floral remnants.

Additional material examined: Brazil. Espírito Santo: Domingos Martins, flowered in cultivation, July 1969, R. Kautsky s.n. (HB!); same locality, flowered in cultivation, without date, F. Dungs s.n. (HB!). Rio de Janeiro: Itatiaia, vicinity of Macieiras, $1960 \mathrm{~m}, 7$ Jan. 1929, J. Ferreira 1716 (US!, S!, AMES!, G!, F!); Itatiaia, trail to meterological station, 25 Dec. 1915, O. Ames 108 (AMES!); Nova Friburgo, Pico da Caledônia, 2200 m, 9 May 2012, A. Bonnet and E. Caglioni 127 (UPCB!); Nova Friburgo, 26 March 1967, F. Dungs s.n. (HB!); Teresópolis, Parque Nacional da Serra dos Órgãos, Trilha Pedra do Sino, entre os abrigos 3 e 4, 1979 m, 23 March 2014, M. Bolson et. al. 505 (UPCB!). Without locality and collector: number 26 (MBML—spirit 6125!); number 27 (MBML—spirit 6126!); number 29 (MBML—spirit 6127!).

Acknowledgments. We thank the Directors and Curators of the herbaria cited in this article for sending specimens on loan or allowing access to their collections. We thank the following herbaria for permission to reproduce images of their herbarium specimens: $\mathrm{BHCB}, \mathrm{BR}, \mathrm{C}$, and $\mathrm{P}$. We are also grateful to Sistema de Autorização e Informação em Biodiversidade/Instituto Chico Mendes de Conservação da Biodiversidade (SISBIO/ICMBio) for the collecting permits, Coordenação de Aperfeiçoamento de Pessoal de
Nível Superior (CAPES) for master fellowship PNADB 17/2009 to CAR, and grant Programa Pesquisador Visitante Especial (PVE), nr. 88881.065009/2014-0, to ALVTB. ECS thanks Conselho Nacional de Desenvolvimento Científico e Tecnológico (CNPq) for grant Bolsa de Produtividade em Pesquisa do CNPq-Nível 2. We also thank Antonio Francisco Marins de Albuquerque for information on the type locality of Phymatidium geiselii, Teresinha Callot (MBML) for her help in obtaining literature and information on specimens deposited at MBML, Kanchi Gandhi (Harvard University Herbaria), for his assistance in resolving some nomenclatural issues, Wade Collier for help in assembling the illustrations, Helena Ignowski for preparing the line drawings, Gustavo A. Romero and Irina Ferrera for their assistance during a recent visit to AMES, and Mônica Bolson for providing material for study.

\section{LiterATURE CITED}

Angely, J. (1973). Flora Analítica e Fitogeográfica do Estado de São Paulo 6. Phyton, São Paulo, p. 1328.

Brade, A. C. (1942). Excursão à Serra do Caparaó. Rodriguésia, 6 (15), 87-92, tab. 1-4, fig. 1-22.

Cabral, P. R. M \& Pansarin, E. R. (2013). Biologia reprodutiva de Phymatidium delicatulum (Orchidaceae) In: Stehmann, J. R., Santos Isaias,R. M., Modolo, L.V., Vale, F. H. A. \& Salino, A. (Eds.) $64^{\circ}$ Congresso Nacional de Botânica: botânica sempre viva e XXXIII ERBOT Encontro Regional de Botânicos MG, BA e ES. Sociedade Botânica do Brasil, Belo Horizonte, MG. Abstract published online: http://www.botanica.org. br/trabalhos-cientificos/64CNBot/resumo-ins20178id4203.pdf

Chase, M. W. \& Toscano de Brito, A. L. V. (2009). Phymatidium. In: Pridgeon, A. M., Cribb, P. J., Chase, M. W. \& Rasmussen, F. N. (Eds) Genera Orchidacearum, Volume 5: Epidendroideae (Part Two) (pp. 322-324). Oxford: Oxford University Press.

Lindley, J. (1833). The Genera and Species of Orchidaceous Plants. Ridgways, Piccadilly, London, p. 209.

Pacek, A., Stpiczyńska, M., Davies, K. L. \& Szymczak, G. (2012). Floral elaiophore structure in four representatives of the Ornithocephalus clade (Orchidaceae: Oncidiinae). Annals of Botany, 110, 809-820.

Porembski, S. \& Barthlott, W. (1988). Velamen radicum micromorphology and classification of Orchidaceae. Nordic Journal of Botany, 8, 117-137.

Reis M. G., Singer, R. B. Gonçalves, R., Marsaioli, A. J. (2006). The chemical composition of the floral oils of Phymatidium delicatulum and Phymatidium tillandsioides (Orchidaceae). Natural Product Communication, 1, 757-761. 
Royer, C. A. (2013). Filogenia, Riqueza, Diversidade e Endemismo de Phymatidium Lindley (Orchidaceae) e Monografia do Gênero para o Estado do Paraná. Msc. Dissertation. Programa de Pós-Graduação em Botânica, Setor de Ciências Biológicas, UFPR, Curitiba, Brazil, $132 \mathrm{pp}$.

Royer, C. A., Toscano de Brito, A. L. V. \& Smidt, E. C. (2014). O gênero Phymatidium (Orchidaceae: Oncidiinae) no estado do Paraná. Rodriguésia, 65, 251-260.

Ruschi, A., Albuquerque, A. F. M., Zipinotti, E. L. \& Ruschi, A. (1976). Orquidáceas novas do Estado do Espírito Santo. Boletim do Museu de Biologia Prof Mello-Leitão, Serie Botânica 85: 1-4.

Toscano de Brito, A. L. V. (1998). Leaf anatomy of Ornithocephalinae (Orchidaceae) and related subtribes. Lindleyana, 13, 234-258.
Toscano de Brito, A. L. V. (1999). Seed morphology of subtribes Ornithocephalinae and Telipogoninae (Maxillarieae: Orchidaceae). Lindleyana, 14, 27-37.

Toscano de Brito, A. L. V. (2001). Systematic review of the Ornithocephalus group (Oncidiinae; Orchidaceae) with comments on Hofmeisterella. Lindleyana, 16, 157-217.

Toscano de Brito, A. L. V. (2007). A taxonomic revision of the genus Phymatidium (Orchidaceae: Oncidiinae). Kew Bulletin, 62, 529-560.

Williams, C. A., Toscano de Brito, A. L. V., Harborne, J. B., Eagles J. \& Waterman, P. G. (1994). Methylated C-glycosylflavones as taxonomic markers in orchids of the subtribe Ornithocephalinae. Phytochemistry, 37, 1045-1053. 
